\title{
Reproductive behavior of the Red-crested Finch Coryphospingus cucullatus (Aves: Thraupidae) in southeastern Brazil
}

\author{
Paulo V.Q. Zima' ${ }^{1} \&$ Mercival R. Francisco ${ }^{2^{*}}$
}

\author{
'Programa de Pós-graduação em Ecologia e Recursos Naturais, Universidade Federal de São Carlos. Rodovia Wash- \\ ington Luís, km 235, 13565-905 São Carlos, SP, Brazil. \\ ${ }^{2}$ Departamento de Ciências Ambientais, Universidade Federal de São Carlos, Campus Sorocaba. Rodovia João \\ Leme dos Santos, km 110, 18052-780 Sorocaba, SP, Brazil. \\ "Corresponding author. E-mail: mercival@ufscar.br
}

\begin{abstract}
Several behavioral aspects of the Red-crested Finch Coryphospingus cucullatus (Statius Müller, 1776) are poorly studied. Here we provide reproductive information on 16 active nests. This information may be valuable to elucidate the phylogenetic relationships of this bird, and to design plans to manage it. Nesting activities occurred from October to February. Clutches consisted of two to three eggs ( $2.06 \pm 0.25)$, which were laid on consecutive days. Incubation usually started the morning the females laid their last egg and lasted $11.27 \pm 0.47$ days. Hatching was synchronous, or happened at a one-day interval. The nestling stage lasted $12 \pm 0.89$ days. Only females incubated the eggs and they fed the young more often than the males did. Overall nesting success, from incubation to fledging, was $28.2 \%$. Nest architecture and egg color proved to be diagnostic characteristics of Coryphospingus, supporting its maintenance as a distinct genus within the recently proposed sub-family Tachyphoninae. Red-crested Finches showed a preference for certain nesting sites, i.e., forest borders or a Cerrado in late regeneration stage. This information can be useful to programs aiming to release illegally trapped individuals.
\end{abstract}

KEY WORDS. Birds, breeding biology, nesting, Tachyphoninae.

Coryphospingus Cabanis, 1851 comprises only two species, the Red-crested Finch, C. cucullatus (Statius Müller, 1776), and the Pileated Finch, C. pileatus (Wied, 1821), which are characterized by a black crown in the males, with a remarkable erectile red down stripe at the centre (RIDGELY \& TUDOR 1994, JARAMILLO 2011). Although these birds have been traditionally considered as Neotropical Finches, they are currently classified as Tanagers of the subfamily Tachyphoninae (Thraupidae) (Burns et al. 2014). BuRns \& RACICO (2009) have proposed their inclusion in Lanio, but more recent phylogenetic analyses using two mitochondrial and four nuclear genes have corroborated the monophyly of Coryphospingus (BuRns et al. 2014). Although not globally threatened, these Tanagers are often victims of trapping by the illegal cage-bird trade in South America (REgUeIRA $\&$ BERNARD 2012), owing to their attractive colors and melodious songs. Systematic trapping has resulted in the extirpation of many local populations (MR FRANCISCO, pers. obs.) of Coryphospingus. There are unresolved issues in the taxonomy of these birds, and a potential need for management (e.g. the reintroduction of individuals confiscated by the police). Despite that, there is little information on their behavior, including their reproduction (DE LA PEÑA 1979, 1987, Sick 1997, Borges \& Marini 2008, Hayes 2014).
The Red-crested Finch is widely distributed from Central-Western Brazil to Uruguay and Southeast Argentina, and isolated subspecies are present in Guyana, Suriname, northeastern Brazil, Ecuador, Peru and Bolivia (RIDGELY \& Tudor 1994, JARAMILLO 2011). It inhabits areas of Cerrado vegetation, sparse and low secondary forests, forest borders, orchards, and other agricultural habitats (RIDGeLY \& TUdOR 1994, SiCK 1997). Nest and egg descriptions were provided, by DE LA PEÑa $(1979,1987)$, and Sick (1997) and HaYes (2014) presented data on clutch size and breeding phenology for a population from Paraguay. Here we present a detailed description of the nesting behavior of the Red-crested Finch. Our specific objectives were: 1) to provide additional data on nests and egg characteristics, clutch size, breeding phenology, duration of the breeding season, and nesting sites for a population of Red-crested Finch from the state of São Paulo, southeastern Brazil, 2) to present the first nestling descriptions, and the first data on length of incubation and nestling periods, nesting success, and parental care, and 3) based on the recent classification of these birds as Tanagers, compare nest architecture and egg features with other Tachyphoninae to infer if these characteristics are diagnostic of Coryphospingus. These 
data may be valuable to elucidate phylogenetic relationships within the subfamily, and may give support to the current and future management plans for this species.

\section{MATERIAL AND METHODS}

We conducted our study at the non-urbanized areas of the campus of São Carlos Federal University, in the city of Sorocaba,

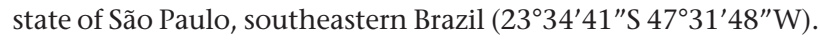
The area is a mosaic with about 40 ha of abandoned artificial pasturelands, with Cerrado vegetation in its initial stages of regeneration; a Cerrado fragment of 1.5 ha in late regeneration stage with 2 to $6 \mathrm{~m}$ tall trees, and three secondary patches of semideciduous Atlantic Forest of 2-3 ha each. The climate is tropical with two well-marked seasons: a humid, hot season from October through March (average rainfall $=919 \mathrm{~mm}$, temperatures range from 15.7 to $32.4^{\circ} \mathrm{C}$ ) and a dry, cold season from April through September (average rainfall $=294 \mathrm{~mm}$, temperature range from 11.4 to $30.6^{\circ} \mathrm{C}$ ).

Search for nets was conducted on the entire area, two to three times per week, from September to February, during two reproductive seasons, 2011/2012 and 2012/2013. Random searches were also performed in 2013/2014 and 2014/2015 seasons. Nests were located by checking the territories defended by males and by following females carrying nest material or delivering food to the nestlings (Martin \& Geupel 1993). Whenever we found a nest, we photographed it, including its eggs and juveniles, the nesting site, and the plant supporting it. Nest type and egg shape were classified according to WINKLER (2004). We used metal calipers accurate to $0.1 \mathrm{~mm}$ to measure nests and eggs, and eggs were weighed to the nearest $0.1 \mathrm{~g}$ using a spring scale. Nests were checked every one to three days and we measured incubation period from the first day of incubation to the day before hatching, and nestling period from hatching day to the day before fledging. These periods were estimated for each egg or young separately by assuming that the first eggs to be laid were also the first to hatch, and that the first young to hatch were the first to fledge (Freitas \& Francisco 2012a, 2012b, DAvANÇo et al. 2013). Only clutches for which we have observed egg-laying from the first to the last egg were considered in clutch size estimation. Focal observations were conducted daily during the laying stage so that we could detect if incubation can begin before or after clutch completion.

Parental care information was obtained by performing $1 \mathrm{hr}$ focal observation sessions, using 8X40 binoculars, during incubation and nestling stages. These observations were always conducted early in the morning (06:00 to 09:00 a.m.), and we estimated the proportion of time females spent in the nest during the incubation stage, and the frequency of feeding visits during the nestling stage. We used the Wilcoxon-Mann-Whitney test to compare the number of times females and males fed the nestlings.

We have considered that the nest was predated when eggs or insufficiently developed nestlings disappeared from a nest; abandoned when adults were not seen near the nests, and eggs were cold for more than two days. We estimated overall nesting success (probability of survival) by the method of MAYFIELD (1961), using the summation of average incubation and nestling periods as exponent. Descriptive statistics are presented as mean \pm SD (Standard Deviation), and statistical analyses were performed using the software R-project 3.2.2 (CORE R TEAM 2013).

\section{RESULTS}

During four breeding seasons we found 16 active nests, mainly in the Cerrado fragment in the late regeneration stages, and at the borders with the Atlantic Forest patches. Pooling these seasons together, the earliest nesting activity has been recorded on 3 October 2012 (a nest in construction), and the latest young observed in a nest was recorded on 18 February 2012. Nests were shaped as cups, and were made of thin flexible materials, including fine petioles, rachis and peduncles of grass inflorescences, and rootlets. Nest walls were compact, with nest material firmly bound together with spider web. The rim of two nests was slightly curved inward. Lining consisted of finer fibers, mainly peduncles of grass inflorescences, and in two nests black fungal filaments were also used. The outer walls of nests can be adorned with a variable amount of pieces of likens and decaying leafs, often reduced to skeletons, which are firmly attached to the nests. Nests were supported from bellow and laterally by multiple small branches that were vertical, horizontal, or in angle. These supporting branches were interlaced to the nest walls in attachment points that were reinforced with spider web (Fig. 1). Nest measurements were: outside diameter $7.41 \pm 0.50$ $\mathrm{cm}$ (range $=6.53-7.94)$, inside diameter $5.29 \pm 0.42 \mathrm{~cm}$ (range $=$ 4.88-6.0), outside height $4.22 \pm 0.47 \mathrm{~cm}$ (range = 3.41-4.92), inside height $3.19 \pm 0.40 \mathrm{~cm}$ (range $=2.73-3.74, \mathrm{n}=7)$, and height above ground $2.04 \pm 0.59 \mathrm{~m}$ (range = 1.37-3.24, $\mathrm{n}=12$ ). The following supporting plants were identified: Zanthoxylum rhoifolium $(\mathrm{n}=1)$, Caryocar brasiliense $(\mathrm{n}=3)$, Didymopanax vinosum $(\mathrm{n}=1)$, Struthanthus vulgaris $(\mathrm{n}=1)$, Pera glabrata $(\mathrm{n}=$ $1)$, Schinus terebinthifolius $(\mathrm{n}=1)$, Machaerium acutifolium $(\mathrm{n}=5)$ (LORENZI 2002, 2008), and the exotic Zea mays $(\mathrm{n}=1)$.

Eggs were short-oval and totally white (Fig. 3). Their measurements were: length $19.26 \pm 0.70 \mathrm{~mm}$ (range = 18.35-20.3); width $14.03 \pm 0.23 \mathrm{~mm}$ (range $=13.65-14.4$ ), and weight 1.9 $\pm 0.17 \mathrm{~g}$ (range $=1.6-2.1)(\mathrm{n}=8$ eggs from four nests). Clutch size was two ( $\mathrm{n}=10$ nests) or three eggs ( $\mathrm{n}=1$ nest), averaging $2.06 \pm 0.25$. Eggs were invariably laid on consecutive days $(\mathrm{n}=$ 11 nests). In seven nests, incubation started the morning the females laid their last egg, and in one nest (the only with three eggs) it started on the day the second egg was laid (Fig. 2). The incubation period varied from 11 ( $n=8$ eggs) to 12 days ( $n=3$ eggs), averaging $11.27 \pm 0.47$ days ( $n=11$ eggs from five nests). Hatching was synchronous in two of five nests, with a one-day interval in the others (including the nest with three eggs). In 15 hours of focal observations of four different nests, only females 

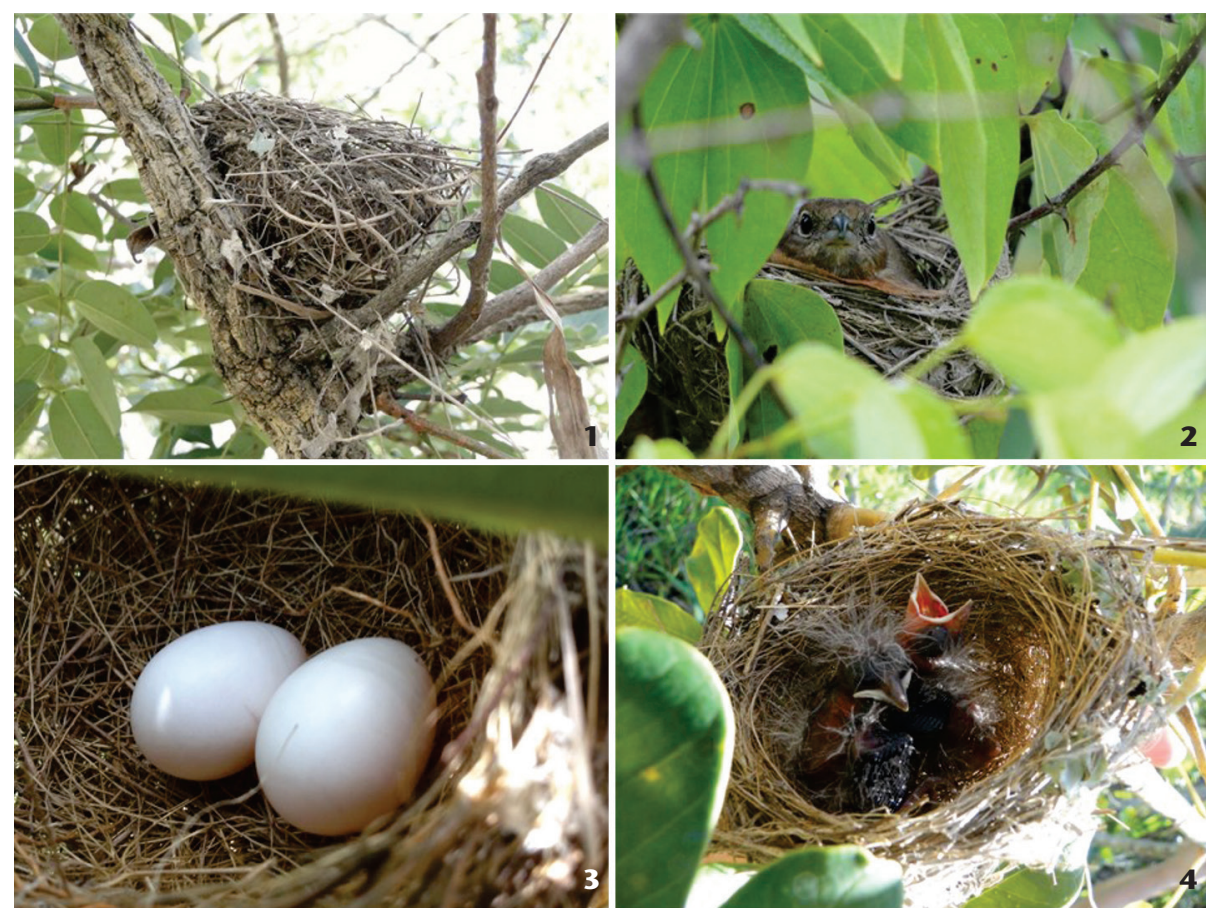

Figures 1-4. Nests, eggs, and young Red-creasted Finch. (1) Nest lateral view depicting nest placement and lichens in the outer wall. (2) Female incubating eggs. (3) Eggs and incubation chamber. (4) Nestlings.

incubated. Males were never observed feeding a female in the nest, but they occasionally escorted them during incubation recesses. During this stage, females spent 2.03-60 min incubating per hour $(25.72 \pm 18.76 \mathrm{~min})$. They left the nests 0 to two times/hour (1.09 \pm 0.83$)$, and incubation recesses varied from 3.78-15.13 $\min (6.32 \pm 4.4)$. Upon hatching, nestlings showed dark red skin and were covered with sparse dark gray down. The bill and swollen flanges were white and mouth lining was bright red (Fig. 4). The nestling stage lasted 11 ( $\mathrm{n}=2$ young), 12 ( $\mathrm{n}=$ $2)$, or 13 days $(n=2)(12 \pm 0.89, n=6$ young from 3 nests $)$. In $12 \mathrm{~h}$ of observation of four nests, young were fed on average $8 \pm$ 3.9 times/hour (range $=4-13$ ). Females fed the young on average $6.4 \pm 2.62$ times/hour (range $=3-11$ ), while males fed them on average $2.0 \pm 1.0$ times/hour (range $=1-4$ ), which means that female participation was significantly greater than that of males ( $\mathrm{W}=23.5, \mathrm{p}=0.02686)$. Only females were observed carrying fecal sacs away ( $\mathrm{n}=4$ times in 2 nests). Fledging of youth always happened on the same day ( $\mathrm{n}=6$ nests), when they still had poorly developed feathers and were very weak flyers.

Of the 13 nests with known fates, the juveniles of five nests fledged successfully (38.5\%), one nest fell down after a heavy storm, one was damaged by humans, two were abandoned in their incubation stage, and four were predated. Only one infertile egg was observed in a nest containing two eggs, and overall nesting success, from incubation to fledging was $28.2 \%$ (151 nest days, $\mathrm{n}=13$ nests).

\section{DISCUSSION}

\section{Nest, eggs, and hatchlings characteristics}

The characteristics of nests and eggs in our study population match the description presented by DE LA PEÑa (1979) of a nest from Santa Fé, Argentina. Nest architecture can be phylogenetically informative in certain groups of birds, but in others they have not corroborated DNA-based phylogenies (GREENEY et al. 2013, Perrella et al. 2015). Coryphospingus has been recently classified in the Tanager subfamily Tachyphoninae, together with 29 other species from Tachyphonus, Trichothraupis, Ramphocelus, Lanio, Volatinia, Conothraupis, Eucometis, Rhodospingus, and Creurgops (Burns et al. 2014). Available information indicates that important variations in nest architecture can be observed within this subfamily, with at least three clearly distinct patterns. First, nests of the Blue-black Grassquit Volatinia jacarina (Linnaeus, 1766) and the Grey-headed Tanager Eucometis penicillata (Spix, 1825 ) are in the shape of cups and are built mostly of rootlets. Although the nest walls are compact, they are so thin that eggs can be seen through them, and they lack any type of adornment (SKutch 1954, Carvalho et al. 2007). Second, nests of the following birds, the Silver-beaked Tanager Ramphocelus carbo (Pallas, 1764) (DE CARVALHO 1957), the Scarlet-rumped Tanager R. passerinii (Bonaparte, 1831) (SкUтсн 1954), the Crimson-backed Tanager $R$. dimidiatus (Lafresnaye, 1837) (Sкuтсн 1954), the Masked Crimson Tanager R. nigrogularis (Spix, 1825) (GREENEY \& SHELDON 2008), the 
Black-and-white Tanager Conothraupis speculigera (Gould, 1855) (Greeney et al. 2006, Ingels 2007), the Crimson-breasted Finch Rhodospingus cruentus (Lesson, 1844) (Marchant 1960), Tachyphonus phoenicius (Haverschidt 1956), and the White-winged Shrike-tanager Lanio versicolor (d'Orbigny \& Lafresnaye, 1837) (Tello 1999), are cups built of elongated fibers, but they have a certain amount of dry leaves in the walls. Further, the outer walls are mostly adorned with leaves that are loosely attached, which often give these nests a more conical appearance from the outside. Third, there are the nests of Coryphospingus spp.: although they build the nest walls from fibers, like species of Volatinia and Eucometis, the walls are dense and highly compact. Pieces of leaves and likens are firmly attached only to the outer layer, instead of being loosely attached, like what happens to species of Ramphocelus, Conothraupis, Rhodospingus, Tachyphonus, and Lanio. Although the Crimson-backed Tanager and the Grey-headed Tanager use spider webs in their nests, the Red-crested Finch seems to use much more of this type of material.

Egg color is also variable within this group of birds, with background color varying from white (Blue-black Grassquit, Black-and-white Tanager, White-lined Tanager Tachyphonus rufus (Boddaert, 1783), and rarely in the Scarlet-rumped Tanager) to greenish (Silver-beaked Tanager, Black-and-white Tanager), bluish (Grey-headed Tanager, Silver-beaked Tanager, Scarlet-rumped Tanager, Crimson-backed Tanager, Masked Crimson Tanager, Cherrie's Tanager Ramphocelus costaricensis (Cherrie, 1891)), pinkish (Black-goggled Tanager Trichothraupis melanops (Vieillot, 1818), Ruby-crowned Tanager Tachyphonus coronatus (Vieillot, 1822)), redish (White-lined Tanager) or greyish (Scarlet-rumped Tanager, Red-shouldered Tanager Tachyphonus phoenicius (Swainson, 1838)), and the spots and blotches are often brownish and concentrated in the larger pole (Silver-beaked Tanager, Black-goggled Tanager, Ruby-crowned Tanager), or they can form a crown near the larger pole (Scarlet-rumped Tanager, Black-and-white Tanager) (Euler 1900, SKUTCH 1950, 1954, Pinto 1953, Haverschmidt 1956, Greeney et al. 2006, Carvalho et al. 2007, Ingels 2007, Greeney \& Sheldon 2008). This is another important distinctive characteristic of Coryphospingus, as these are the only tanagers that have completely white eggs. A preliminary description of the nest of the congener Pileated Finch indicates that its nest architecture is similar to the nest of the Red-crested Finch, and confirmed that egg color is also completely white (Borges \& MARINI 2008). Although, to our knowledge, there is no nesting information on Creurgops, our early comparative insights indicate that the nest architecture and egg characteristics are diagnostic of Coryphospingus, and suggest that Coryphospingus should be maintained as a distinct genus within the Tachyphoninae. The nestlings of many species within this group remain undescribed, and the characteristics of Red-crested Finch hatchlings match those of the White-winged Shrike-tanager and Grey-headed Tanager. The skin of the Scarlet-rumped Tanager and the Crimson-backed Tanager is pink (SKuTCh 1954, Tello 1999).

\section{Breeding phenology and nesting behavior}

While many non-forest passerines in south-central Brazil start reproduction during the end of the dry season in late August or early September, e.g. pipits, thrushes, and flycatchers (PIRATELLI et al. 2000, Marini \& Durães 2001, Freitas \& Francisco 2012a, Davanço et al. 2013), the breeding season of the Red-crested Finch starts a little later, matching the breeding phenology found for the granivorous finches from the region, which reproduce during the peak of the rainy season (Francisco 2006, Oliveira et al. 2010, Freitas \& Francisco 2012b). Hayes (2014) also reported a breeding season from October to February in Sapucái, Paraguay $\left(25^{\circ} 40^{\prime} \mathrm{S}\right.$ $56^{\circ} 55^{\prime} \mathrm{W}$ ), with a reproductive peak on November and December.

Within the Tachyphoninae, clutch sizes of two to three eggs have also been found for the Blue-black Grassquit (CARVALHO et al. 2007), the Grey-headed Tanager (SKUTCH 1954), the Silver-beaked Tanager (DE CaRvalHo 1957), the Scarlet-rumped Tanager (SкUтсн 1954), the Crimson-backed Tanager (SкUтсн 1954), the Masked Crimson Tanager (Greeney \& Sheldon 2008), the White-lined Tanager (GefFen \& Yom-Tov 2000), and the Ruby-crowned Tanager (Euler 1900). Exceptions are the Black-andwhite Tanager (3-4 eggs, Ingels 2007), and the Crimson-breasted Finch (2-4, mean 3.21, Marchant 1960). Average clutch sizes of 2.5 found for the Red-crested Finch in Argentina by HAYES (2014) are slightly greater than what we found, indicating a higher frequency of three eggs clutches in his study site, and that mean clutch size may varying between populations. The incubation period of 11 days for most eggs is short among the Tachyphoninae. Only the Crimson-breasted Finch (MARCHANT 1960) and the Blue-black Grassquit (CARvalHo et al. 2007) have incubation periods of 10-12 and 10-11 days, respectively. In the other representatives, incubation periods were longer: Grey-headed Tanager (14-16 days, SкUTCH 1954), White-lined Tanager (14-15 days, Peixoto Velho 1932, Tieleman et al. 2004), Scarlet-rumped Tanager (12 days, SкUTCH 1954), Cherrie's Tanager (12-13 days, SkUTCH 1950), and Silver-beaked Tanager (12 days, DE Carvalho 1957, Ingels 1978, de Melo Valente 2000). The nestling period of 12 days is similar to that found for the Grey-headed Tanager (11-12 days, SкUTCH 1954), the Scarlet-rumped Tanager (11-12 days, SкUTCH 1954), and the Cherrie's Tanager (11-13 days, SKUTCH 1954), but some species have shorter periods, e.g. the Crimson-backed Tanager (10-11 days, Allen 1905), the Blue-black Grassquit (10 days, Carvalho et al. 2007), and the Crimson-breasted Finch (7-9 days, Marchant 1960).

Parental care information is scarce among the Tachyphoninae. Incubation performed only by the females and the less intensive participation of males in nestling provisioning has also been observed in the Grey-headed Tanager (SKUTCH 1954). This pattern is different from that found for the Blue-black Grassquit, in which males share both incubation and nestling provisioning with the females (CARvalHo et al. 2007). Notably, incubating females of the Red-crested Finch were reluctant to leave the nest when the observer approached it, allowing herself to be touched in the nest. We suspect that this behavior 
could be related to the color of the eggs. Pigments are believed to contribute to egg camouflage (NGUYen et al. 2003, STODdARD et al. 2011, Lovell et al. 2013). Corroborating this hypothesis, white eggs are present more often in cavity-nesters, and are not exposed to visual predators (WINKLER 2004). Conversely, white eggs are rare among open-nesters, with rare exceptions among the Doves, Hummingbirds, and some Flycatchers (SKUTCH 1954). Future work is needed to elucidate if this uncommon female behavior (remaining in the nest when disturbed) has evolved to minimize the detection of white eggs in open nests. SICK (1997) has reported that nests of Red-crested Finches can be parasitized by the Shiny Cowbird Molothrus bonariensis (Gmelin, 1789). Although we have observed Shiny Cowbird parasitism in other species in the same study area, e.g. Rufous-collared Sparrows Zonotrichia capensis (Müller, 1776) (pers. obs.), Red-crested Finch nests were never parasitized. Under a conservation perspective, nesting biology information can be helpful in the management of bird species that, like the Coryphospingus spp., suffer the impact of illegal pet trade. These data can contribute, for instance, to the parameterization of viability analyses of exploited populations (STREM \& BouzAT 2012), and to the choice of areas for the reintroduction of animals confiscated by the police. Although Pileated-seed Finch can occur in disturbed habitats, in our study area they have reproduced only in locations with minimal habitat requirements, e.g. the borders of forested areas or in a Cerrado in late regeneration stage.

\section{ACKNOWLEDGMENTS}

We are grateful to Pró-Reitoria de Pós-Graduação e Pesquisa from Universidade Federal de São Carlos (UFSCar) for financial support, and M.N. Schlindwein, A.J. Piratelli, and an anonymous referee for important comments on the early versions of this manuscript.

\section{LITERATURE CITED}

AlLEN JA (1905) Supplementary notes on birds collected in the Santa Marta District, Colombia, by Herbert H. Smith, with descriptions of nests and eggs. Bulletin of the American Museum of Natural History 21: 275-295.

Borges FJA, Marini MÂ (2008) Primeira descrição do ninho do mineirinho (Charitospiza eucosma) no cerrado do Brasil Central. Revista Brasileira de Ornitologia 16: 38-39.

BuRns KJ, RACicot RA (2009) Molecular phylogenetics of a clade of lowland Tanagers: Implications for avian participation in the great American interchange. The Auk 126: 635-648. doi: 10.1525/auk.2009.08195

Burns KJ, Shultz AJ, Title PO, Mason NA, Barker FK, Klicka J, Lanyon SM, LovetTe IJ (2014) Phylogenetics and diversification of tanagers (Passeriformes: Thraupidae), the largest radiation of Neotropical songbirds. Molecular Phylogenetics and Evolution 75: 41-77. doi: 10.1016/j.ympev.2014.02.006
Carvalho CBV, Macedo RHF, Graves JA (2007) Reproduction of Blue-black Grassquits in central Brazil. Revista Brasileira de Biologia 67: 275-281. doi: 10.1590/S1519. 69842007000200012

Core R Team (2013) R: A language and environment for statistical computing. Vienna, R Foundation for Statistical Computing. Available online at: http://www.R-project.org/ [Accessed: 10/08/2013]

Davanço PV, Oliveira LS, Sousa LMS, Francisco MR (2013) Breeding life-history traits of the Pale-breasted Thrush (Turdus leucomelas) in southeastern Brazil. Ornitologia Neotropical 24: 401-411.

de Carvalho CT (1957) Notas sobre a biologia do Ramphocelus carbo. Boletim do Museu Paraense Emílio Goeldi, Nova Série Zoologia, 5: 1-20.

de la Peña MR (1979). Nidos de aves de Santa Fé. iv. El Hornero 74: $72-74$.

DE LA PEÑA MR (1987) Nidos and huevos de aves argentinas. Santa Fe, Talleres Gráficos.

de Melo Valente R (2000) Muda e reprodução em Ramphocelus carbo (Passeriformes, Emberizidae) na Amazônia brasileira. Ararajuba 8: 135-139.

Euler C (1900) Descrição de ninhos e ovos das aves do Brasil. Revista do Museu Paulista 4: 9-148.

Francisco MR (2006) Breeding biology of the Double-collared Seedeater (Sporophila caerulescens). The Wilson Journal of Ornithology 118: 85-90. doi: 10.1676/1559-4491(2006)118[0085:BBOTDS]2.0.CO;2

Freitas MS, Francisco MR (2012a) Reproductive life history traits of the Yellowish Pipit (Anthus lutescens). The Wilson Journal of Ornithology 124: 119-126. doi: 10.1676/11-038.1

Freitas MS, Francisco MR (2012b) Nesting behavior of the Yellow-Finch (Sicalis luteola) in southeastern Brazil. Ornitologia Neotropical 23: 341-348.

Gefren E, Yom-Tov Y (2000) Are incubation and fledging periods longer in the tropics? Journal of Animal Ecology 69: 59-73. doi: 10.1046/j.1365-2656.2000.00370.x

Greeney HF, JuiÑa M, Sornoza FA (2006) Nest descriptions for Conothraupis speculigera and Thlypopsis ornata in Ecuador. Boletín de la Sociedad Antioqueña de Ornitología 16: 24-29.

Greeney HF, SHeLdon KS (2008) The nest and eggs of the Masked Crimson Tanager (Ramphocelus nigrogularis). Cotinga 30: 80-81.

Greeney HF, SÁnchez C, Sánchez JE \& Carman E (2013) A review of nest and egg descriptions for the genus Myrmeciza, with the first description of nests and eggs of the dull-mantled antbird (M. laemosticta). Journal of Ornithology 154: 1049-1056. doi: 10.1007/s10336-013-0973-0

HAVERSCHMIDT F (1956) The nest and egg of Tachyphonus phoenicius. Wilson Bulletin 68: 322-323.

HAyes FE (2014) Breeding season and clutch size of birds at Sapucái, Departamento Paraguarí, Paraguay. Boletín Del Museo Nacional de Historia Del Paraguay 18: 77-97. 
InGELS J (1978) The nesting of three tanagers common in French Guiana. Avicultural Magazine 84: 105-110.

INGELS J (2007) Additional information on the breeding biology of the Black-and-white Tanager (Conothraupis speculigera) in Ecuador. Boletim de la Sociedad Antioqueña de Ornitología 17: 98-103.

Jaramillo A (2011) Red-crested Finch (Coryphospingus cucullatus). In: Del Hoyo J, Elliot A, Sargatal J, Christie DA, de Juana E (Eds.) Handbook of the Birds of the World Alive. Barcelona, Lynx Edicions.

LORENZI H (2002) Árvores Brasileiras: Manual de identificação e cultivo de plantas arbóreas nativas do Brasil. Nova Odessa, Instituto Plantarum, vol. 2, 384p.

LORENZI H (2008) Árvores Brasileiras: Manual de identificação e cultivo de plantas arbóreas nativas do Brasil. Nova Odessa, Instituto Plantarum, vol. 1, 380p.

Lovell PG, Ruxton GD, LANGridge KV, Spencer KA (2013) Egg-laying substrate selection for optimal camouflage by quail. Current Biology 23: 260-264. doi: 10.1016/j.cub.2012.12.031

Marchant S (1960) The breeding of some S.W. Ecudorian birds. Ibis 102: 584-599.

MARINI MA, DURÃES R (2001) Annual patterns of molt and reproductive activity of passerines in south-central Brazil. Condor 103: 767-775. doi: 10.1650/0010-5422(2001)103[0767:APOMAR]2.0.CO;2

Martin TE, Geupel RG (1993) Nest-monitoring plots: methods for locating nests and monitoring success. Journal of Field Ornithology 64: 507-519.

MAYFIELd H (1961) Nesting success calculated from exposure. The Wilson Bulletin 73: 255-261.

Nguyen LP, Nol E, Aвraham KF (2003) Nest success and habitat selection of the semipalmated plover on Akimiski Island, Nunavut. Wilson Bulletin 115: 285-291. doi: 10.1676/03-044

Oliveira LS, Sousa LMS, Davanço PV, Francisco MR (2010) Breeding behavior of the Lined Seedeater (Sporophila lineola) in southeastern Brazil. Ornitologia Neotropical 21: 251-261.

Peixoto Velho PP (1932) Descrição de alguns ovos de aves do Brasil existentes nas coleções do museu. Boletim Museu Nacional Rio Janeiro Zoologia 8: 49-60.

Perrella DF, Biagolini-Júnior CH, Ribeiro-Silva L, Zima PVQ, Galetti JR PM, Francisco MR (2015) Nest, eggs, and nestlings of the Atlantic Forest endemic Star-throated Antwren (Rhopias gularis). The Wilson Journal of Ornithology 127: 322-326. doi: 10.1676/wils-127-02-319-323.1

PInTo OMO (1953) Sobre a coleção Carlos Estevão peles, ninhos e ovos das aves de Belém (Pará). Papéis Avulsos do Departamento de Zoologia 11: 113-224.
Piratelli AJ, Siqueira MAC, Marcondes-Machado LO (2000) Reprodução e muda de penas em aves de sub-bosque na região leste do Mato Grosso do Sul. Ararajuba 8: 90-107.

REgUeIRA RFS, BERNARD E (2012) Wildlife sinks: Quantifying the impact of illegal bird trade in street markets in Brazil. Biological Conservation 149: 16-22. doi: 10.1016/j.biocon.2012.02.009

Ridgely RS, Tudor G (1994) The birds of South America: Volume II: The Suboscine Passerines. Austin, University of Texas Press, 940p.

SICK H (1997) Ornitologia Brasileira. Rio de Janeiro, Nova Fronteira, 912p.

SKUTCH AF (1950) Outline for an ecological life history of a bird, based upon the Song Tanager Ramphocelus passerinii costaricensis. Ecology 31: 464-469.

SкUTCH AF (1954) Life histories of Central America birds (families: Fringillidae, Thraupidae, Icteridae, Parulidae and Coerebidae). Pacific Coast Avifauna 31: 123-261.

Stoddard MC, Marshall KLA, Kilner M (2011) Imperfectly camouflaged avian eggs: artefact or adaptation? Avian Biology Research 4: 196-213. doi: 10.3184/175815511X13207484398647

Strem RI, Bouzat JL (2012) Population viability analysis of the Blue-throated Macaw (Ara glaucogularis) using individual-based and cohort-based PVA programs. The Open Conservation Biology Journal 6: 12-24. doi: 10.2174/1874839201206010012

TelLo JG (1999) First description of nest and nestlings of Whitewinged Shrike-Tanager Lanio versicolor. Cotinga 11: 81-82.

Tieleman BI, Williams JB, Ricklefs RE (2004) Nest attentiveness and egg temperature do not explain the variation in incubation periods in tropical birds. Functional Ecology 18: 571-577.

WINKLER DW (2004) Nests, eggs, and young: breeding biology of birds, p. 8.1-8.152. In: Podulka S, Rohrbaugh Jr RW, Bonney R (Eds.) Cornell Lab of Ornithology Handbook of Bird Biology. Princeton, Princeton University Press, 1248p.

Submitted: 20 April 2016

Received in revised form: 8 May 2016

Accepted: 30 June 2016

Editorial responsibility: Luís Fábio Silveira

Author Contributions: PVQZ and MRF participated equally in the preparation of this article.

Competing Interests: The authors have declared that no competing interests exist. 